\title{
Thermal Zones Modelling for an Energy Efficient Commercial Building - Case Study
}

\author{
Elena Camelia Tamaş (Papuc) $)^{1, *}$, Dragoş Hera ${ }^{2}$, Gianni Flamaropol ${ }^{3}$, and Graţiela Maria Ţârlea ${ }^{4}$ \\ ${ }^{1}$ Technical University of Civil Engineering, Faculty of Building Services, 66 Bvd. Lacul Tei, Bucharest, Romania \\ ${ }^{2}$ Technical University of Civil Engineering, Faculty of Building Services, 66 Bvd. Lacul Tei, Bucharest, Romania \\ ${ }^{3}$ Technical University of Civil Engineering, Faculty of Building Services, 66 Bvd. Lacul Tei, Bucharest, Romania \\ ${ }^{4}$ Technical University of Civil Engineering, Faculty of Building Services, 66 Bvd. Lacul Tei, Bucharest, Romania
}

\begin{abstract}
Our paper is referring to a commercial building having a good thermal insulation, compacted shape with three basements, from which two are for parking and technical areas in the underground, and the other floors are mainly for retail, technical rooms, offices and a terrace for walking and events. The methodology used in our building thermal zones modelling analysis is including: all used measured areas within the building; all materials related to the building envelope with high thermal efficiency values; all activities performed within the respective areas; the heating and cooling activities for each zone; the lighting and controls used for each zone; the building geometry related to the data requirements, loads, air conditioning and lighting systems areas; the building usage schedules; Heating Ventilation and Air Conditioning (HVAC) and electrical system specifications along the weather data. The building thermal zones modelling simulation was performed based on the air set point temperature, ventilation fresh air rate and the room destination. After monitoring the building along four operational years, the energy consumptions for heating and cooling systems were obtained for each thermal zone and for the entire building. Some technical measures to improve the building energy performances are proposed based on the monitoring period.
\end{abstract}

\section{Introduction}

This article is regarding the thermal zones modelling analysis for a big size commercial building in Romania. The final building design project, which was based for the building execution, before the execution period, suffered two major design updates:

- the first one was performed to study the indoor conditions in different thermal zones of the building, which had a total volume of $536.437,46 \mathrm{~m}^{3}$, a total gross area of $114.318,07 \mathrm{~m}^{2}$, planning to obtain losses through building envelope and heating requirements for fresh air intake to the building for human needs as of $4.189,00 \mathrm{~kW}[1]$;

- the second one was made to improve the first considerations and to implement a part of them into the new construction building project [2] to obtain a better building design and an energy efficient monitored building. For this updated design, we have $149,32 \mathrm{kWh} / \mathrm{m}^{2 *}$ year total building annual specific consumption with $21,58 \mathrm{~kg}_{\mathrm{CO} 2} / \mathrm{m}^{2 *}$ year equivalent specific annual emission indicator. For an average year, during the monitored months, there were reached $7.830,00 \mathrm{MWh} /$ year for building heating and $0,847 \mathrm{MWh} /$ year for building cooling. [3].

The new construction building project have the followings data to consider: $337.274,00 \mathrm{~m}^{3}$ interior volume, $547.00,00 \mathrm{~m}^{2}$ heated area for the building levels (as $1^{\text {st }}$ Basement, 1B, Ground Floor, GF, $1^{\text {st }}, 1 \mathrm{~F}$ and $2^{\text {nd }}$ Floor, 2F), implemented non-transparent construction elements with excellent thermal insulation coefficients [2].

Our methodology is including for all building levels, the thermal modelling zones chosen based on the building physic description, the building services systems, the indoor set point temperatures, the fresh air supplies, the extract and recirculation rates, the occupational levels and the internal heat gains [2], as follows briefly within the table 1 :

Table 1. Building thermal modelling zones

\begin{tabular}{|c|c|c|c|c|}
\hline Zone type & $\begin{array}{c}\text { Indoor } \\
\text { set point } \\
\text { tempera- } \\
\text { tures }\left({ }^{0} \mathrm{C}\right) \\
\text { (no } \\
\text { humidity } \\
\text { control) }\end{array}$ & 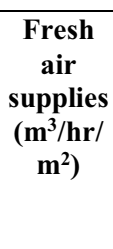 & $\begin{array}{c}\text { Extract/ } \\
\text { Recircu- } \\
\text { lation } \\
\text { rates } \\
(\%)\end{array}$ & $\begin{array}{c}\begin{array}{c}\text { Internal } \\
\text { heat } \\
\text { gains } \\
\left(\mathbf{W} / \mathbf{m}^{2}\right)\end{array} \\
\end{array}$ \\
\hline $\begin{array}{l}\text { Shops> } \\
1000 \mathrm{~m}^{2}\end{array}$ & $\begin{array}{l}22^{0} \mathrm{C} \pm 2 \mathrm{~K} \\
\text { (winter)/ } \\
24^{0} \mathrm{C} \pm 2 \mathrm{~K} \\
\text { (summer) }\end{array}$ & 9 & $\begin{array}{c}60 \% \\
\text { recircu- } \\
\text { lation, } \\
40 \% \\
\text { fresh air }\end{array}$ & 30 \\
\hline
\end{tabular}

\footnotetext{
* Corresponding author: cam358456@yahoo.fr
} 


\begin{tabular}{|c|c|c|c|c|}
\hline $\begin{array}{l}\text { Shops }< \\
1000 \mathrm{~m}^{2}\end{array}$ & $\begin{array}{l}22^{0} \mathrm{C} \pm 2 \mathrm{~K} \\
\text { (winter)/ } \\
24^{0} \mathrm{C} \pm 2 \mathrm{~K} \\
\text { (summer) }\end{array}$ & 5 & $\begin{array}{c}100 \% \\
\text { fresh air }\end{array}$ & 30 \\
\hline $\begin{array}{c}\text { Technical } \\
\text { area }\end{array}$ & $15^{\circ} \mathrm{C} \pm 2 \mathrm{~K}$ & 5 & $\begin{array}{c}85 \% \\
\text { recircu- } \\
\text { lation }\end{array}$ & 5 \\
\hline $\begin{array}{l}\text { Building } \\
\text { public area }\end{array}$ & $\begin{array}{l}22^{0} \mathrm{C} \pm 2 \mathrm{~K} \\
\text { (winter)/ } \\
24^{0} \mathrm{C} \pm 2 \mathrm{~K} \\
\text { (summer) }\end{array}$ & 5 & $\begin{array}{c}100 \% \\
\text { fresh air, } \\
\text { heat } \\
\text { recovery }\end{array}$ & 20 \\
\hline Offices area & $\begin{array}{l}22^{0} \mathrm{C} \pm 2 \mathrm{~K} \\
\text { (winter)/ } \\
24^{0} \mathrm{C} \pm 2 \mathrm{~K} \\
\text { (summer) }\end{array}$ & 5 & $\begin{array}{l}60 \% \\
\text { recircu- } \\
\text { lation }\end{array}$ & 30 \\
\hline $\begin{array}{c}\text { Conference } \\
\text { area }\end{array}$ & $\begin{array}{l}22^{0} \mathrm{C} \pm 2 \mathrm{~K} \\
\text { (winter)/ } \\
24^{0} \mathrm{C} \pm 2 \mathrm{~K} \\
\text { (summer) }\end{array}$ & 9 & $\begin{array}{l}85 \% \\
\text { recircu- } \\
\text { lation }\end{array}$ & 30 \\
\hline $\begin{array}{c}\text { Management } \\
\text { area }\end{array}$ & $\begin{array}{l}22^{0} \mathrm{C} \pm 2 \mathrm{~K} \\
\text { (winter)/ } \\
24^{0} \mathrm{C} \pm 2 \mathrm{~K} \\
\text { (summer) }\end{array}$ & 5 & $\begin{array}{l}85 \% \\
\text { recircu- } \\
\text { lation }\end{array}$ & 30 \\
\hline Storage area & $\begin{array}{c}17^{0} \mathrm{C} \pm 2 \mathrm{~K} \\
\text { (winter), } \\
\text { no cooling }\end{array}$ & 5 & $\begin{array}{l}90 \% \\
\text { recircu- } \\
\text { lation }\end{array}$ & 5 \\
\hline Toilets area & $20^{\circ} \mathrm{C} \pm 2 \mathrm{~K}$ & $\begin{array}{c}10 \mathrm{a} / \mathrm{c} \\
\text { per hour } \\
\text { extract }\end{array}$ & $100 \%$ & 20 \\
\hline $\begin{array}{l}\text { Change } \\
\text { rooms area }\end{array}$ & $\begin{array}{l}22^{0} \mathrm{C} \pm 2 \mathrm{~K} \\
\text { (winter)/ } \\
20^{\circ} \mathrm{C} \pm 2 \mathrm{~K} \\
\text { (summer) }\end{array}$ & 5 & $\begin{array}{c}100 \% \\
\text { fresh air }\end{array}$ & 30 \\
\hline $\begin{array}{c}\text { Supermarket } \\
\text { area }\end{array}$ & $\begin{array}{l}22^{0} \mathrm{C} \pm 2 \mathrm{~K} \\
\text { (winter)/ } \\
24^{0} \mathrm{C} \pm 2 \mathrm{~K} \\
\text { (summer) }\end{array}$ & 9 & $\begin{array}{c}100 \% \\
\text { fresh air, } \\
\text { heat } \\
\text { recovery }\end{array}$ & 30 \\
\hline
\end{tabular}

Note*: Based on the occupational levels, we considered for the internal heat gains values as follows: 1 person $/ 6 \mathrm{~m}^{2}$ for shops smaller than $1000 \mathrm{~m}^{2}$ and the same value for the building public area; 1person $/ 3 \mathrm{~m}^{2}$ for the shops area bigger than $1000 \mathrm{~m}^{2}$; 1 person $/ 10 \mathrm{~m}^{2}$ for offices, management and conference areas; and 1 person $/ 1 \mathrm{~m}^{2}$ for the building public areas.

To understand better our modelling, we present the building description and the thermal zones per each level and zone. We analyzed the obtained building energy performances for the executed building to resume how the building will operate in the most efficient way.

\section{Building description}

\subsection{Building physics description}

The building elements are basically two types: opaque and transparent. The opaque elements are walls, floors and roofs and the transparent ones are windows, skylights and curtain walls.

The external walls are two types, one has thermal resistance including thermal bridges $R^{\prime}=2.60 \mathrm{~m}^{2} \mathrm{~K} / \mathrm{W}$ (for plasterboard, air, insulation, air) and the other one has $\mathrm{R}^{\prime}=3.50 \mathrm{~m}^{2} \mathrm{~K} / \mathrm{W}$ (plaster/aerated concrete/plaster). The external walls are aluminium material comprising of flat and curved panels mounted on steel or aluminium framework. Structural insulated flat and curved glazing within thermally broken plastic-coated aluminium frames, further mounted on aluminium frames and/or spider system within the external panel system. LED advertising screens set in compact or elongated areas of the external walls. Sandwich panels faced externally with applied finishes including paint on render, selected stone, and single skin plastic coated cladding systems; with thermal insulation to obtain a target factor of $U=0.50 \mathrm{~W} / \mathrm{m}^{2} \mathrm{~K}$.

All external glazing elements between heated or conditioned interior and outside air have the following characteristics: overall $\mathrm{U}=1.1 \mathrm{~W} / \mathrm{m}^{2} \mathrm{~K} ; \mathrm{g}=0.35$; the external glazed element is $6 \mathrm{~mm}$ thick anti-sun glazing; the internal glazed element will be $6 \mathrm{~mm}$ thick low-e glazing; the gas between the two glazing sections is Argon; the assembly of aluminium frames and the double glazing is to provide a factor of $U=$ $1.39 \mathrm{~W} / \mathrm{m}^{2} \mathrm{~K}$.

The internal walls are four types, first has $\mathrm{R}^{\prime}=1.20 \mathrm{~m}^{2} \mathrm{~K} / \mathrm{W}$ (including plaster, aerated concrete, plaster), second one has $\mathrm{R}^{\prime}=1.80 \mathrm{~m}^{2} \mathrm{~K} / \mathrm{W}$ (with plaster, mineral wool, plaster), third one has $R^{\prime}=1.70 \mathrm{~m}^{2} \mathrm{~K} / \mathrm{W}$ (including plaster, aerated concrete, plaster) and fourth has $\mathrm{R}^{\prime}=4.00 \mathrm{~m}^{2} \mathrm{~K} / \mathrm{W}$ (including plaster, aerated concrete, insulation and plaster).

The trafficable roof has $\mathrm{R}^{\prime}=5.15 \mathrm{~m}^{2} \mathrm{~K} / \mathrm{W}$ (including gravel, insulation, slope and concrete). The nontrafficable roof has $\mathrm{R}^{\prime}=5.00 \mathrm{~m}^{2} \mathrm{~K} / \mathrm{W}$ (including deck, gravel, insulation, slope and concrete).

The floor between first basement and second basement has $\mathrm{R}^{\prime}=3.20 \mathrm{~m}^{2} \mathrm{~K} / \mathrm{W}$ (has an additional layer of $5 \mathrm{~cm}$ extruded polystyrene).

For the transparent elements the solar absorptance is 0.6 with the frame window of $0.1 \% / 100$ and a $g$-value of $0.605 \% / 100$. The windows and skylights are double glazing types and have $\mathrm{R}^{\prime}=1.00 \mathrm{~m}^{2} \mathrm{~K} / \mathrm{W}$.

The curtain walls in the exterior glass façade, including the exterior doors have aluminum profiles. The façade exterior cladding on curved bond and the double-glazed vision areas on spider and curtain wall façade were produced by different suppliers.

The straight and curved bond panels have the same producer and a part of the spider system façade was produced by a different producer.

A trapezoidal sheet was used for steel roof.

Regarding the insulation, there were used mineral wool for basements and insulation boards panels for basements and pantry ceilings and mineral wool between façade and slab air rock. The PVC membrane was used for roof and terrace.

The principal roofs consist of a thermally insulated system to provide a target factor $\mathrm{U}=0.30 \mathrm{~W} / \mathrm{m}^{2} \mathrm{~K}$.

The roof glazing panels were constructed of glass within a plastic-coated aluminium frame to provide a target insulation factor of $\mathrm{U}=1.50 \mathrm{~W} / \mathrm{m}^{2} \mathrm{~K}$. 
A mineral rock wool was used at the top of the walls. The very efficient adhesives were used on the thermal insulation system of the façade.

Regarding the main external access doors, they comprise an automatic, circular, rotating door with single leaf escape doors to both sides finished to match surrounding elevational treatments. All these glazed elements are of double skin laminated security glass and all furniture are in stainless steel and in accordance with the requirements of the fire scenario. The assembly of aluminium frames and the double glazing for these main access doors provides a factor of $\mathrm{U}=1.40 \mathrm{~W} / \mathrm{m}^{2} \mathrm{~K}$.

The external fire escape doors at the ground floor level are double leaf, metal powder coated doors, with laminated security glass, and where necessary, within matching metal frames. All door furniture is in accordance with the fire scenario and door schedule list. This assembly of door panel and frame provide a factor of $\mathrm{U}=1.40 \mathrm{~W} / \mathrm{m}^{2} \mathrm{~K}$.

Referring to the external personnel access doors, these are single leaf plastic coated aluminium or acrylic mat glazed door panels with laminated security glass, within matching aluminium frames. All door furniture is in accordance with the fire scenario. These doors and frames to the thermally insulated provide a factor of $\mathrm{U}=1.40 \mathrm{~W} / \mathrm{m}^{2} \mathrm{~K}$.

The external delivery dock doors are electrically operated, plastic faced aluminium sectional, vertical sliding type with vision panels with chain operation in the event of electrical power failure. These doors and frames to the thermally insulated provide a factor of $\mathrm{U}=1.40 \mathrm{~W} / \mathrm{m}^{2} \mathrm{~K}$.

\subsection{Building services assessment}

All heating and cooling systems are used to follow correctly the design parameters [3] (such as external conditions; internal conditions for space temperatures; noise criteria for HVAC equipment; fresh air supplies; extract and recirculation rates; fresh air ventilation rates; internal heat gains; lighting levels; electrical loads; electrical balance; building areas; building heights; occupational levels) and tenant's specific requirements. All heating and cooling equipment are sized to follow the external conditions described by the design parameters. All fans and heating and cooling pumps are inverted controlled to allow set back in off peak periods or night time thus conserving energy usage.

The general building heating is mainly done by $2 \mathrm{X}$ $1950 \mathrm{~kW}$, low pressure hot water boilers $80^{\circ} / 60^{\circ} \mathrm{C}$ with mixed burners natural gas and diesel fuels. The building public areas are heated using individual roof mounted air handling units (AHU) complete with heat exchangers heating and cooling coils. All corridors and toilets are heated with wall mounted radiators and the ground floor delivery areas are equipped with heaters. All 24 AHUs have chilled water-cooling coils connected to rooftop 2 X $2930 \mathrm{~kW}$ centrifugal chillers and heating coils connected to rooftop boiler plant.
Ventilation, heating and air conditioning of the building public areas are ensured by 4 rooftop AHU units with connections from boiler and chiller plant. The ventilation system treats the entire volume of air. Introduction to the occupied areas are via jet flow diffusers. The system is controlled by variable speed fans and temperature by space temperature sensors and return air detectors.

Shop retail units under $1000 \mathrm{~m}^{2}$ are equipped with a LOOP system utilizing cooling towers ensuring optimum running costs. Shop retail units with more than $1000 \mathrm{~m}^{2}$ are conditioned using a combined ventilation, heating and cooling system based on optimum fresh air requirements and room/supply differentials of less than $9^{0} \mathrm{~K}$.

Building public areas are conditioned conventionally and boosted with energy saving de- stratification fans saving up to $5 \%$ running costs in both winter and summer months.

The domestic cold-water use is minimized by utilizing rain water for all technical water items including cooling tower usage, irrigation requirements, water displays and ponds, car washing needs, sprinkler water, hydrant water for both internal and external hydrants, and additionally treated for toilets requirements.

The car park ventilation is carried out by utilizing up to date technology in the form of induction units formatted to give smoke clearance characteristics. Slow down features for all escalators and travellators were incorporated to reduce electrical energy consumption. Vitiated air from small retail units are used to preheat/cool car park areas. A standby generator is ensuring $30 \%$ back up to maintain all electrical feeds to safety systems. Full use of building management system (BMS) technology [3] is employed to control and monitor the power consumption, environments and the technical parameters. The software used for the BMS system is IEC 61131-3 [4] with a MOVICON application [5].

\section{Building energy performances per thermal zones}

As mentioned above in the introduction chapter, the building modelling thermal zones described within the Table 1 and they are present for all 4 building levels (1B; GF; 1F; 2F) as follows in the table 2:

Table 2. Zone type per building level

\begin{tabular}{|c|c|c|c|c|}
\hline Zone type & 1B & GF & $\mathbf{1 F}$ & 2F \\
\hline $\begin{array}{c}\text { Shops }> \\
1000 \mathrm{~m}^{2}\end{array}$ & yes & yes & yes & yes \\
\hline $\begin{array}{c}\text { Shops }< \\
1000 \mathrm{~m}^{2}\end{array}$ & yes & yes & yes & yes \\
\hline $\begin{array}{c}\text { Technical } \\
\text { area }\end{array}$ & yes & yes & yes & yes \\
\hline $\begin{array}{c}\text { Building } \\
\text { public area }\end{array}$ & yes & yes & yes & yes \\
\hline
\end{tabular}




\begin{tabular}{|c|c|c|c|c|}
\hline Offices area & yes & yes & no & yes \\
\hline $\begin{array}{c}\text { Conference } \\
\text { area }\end{array}$ & no & no & no & yes \\
\hline $\begin{array}{c}\text { Management } \\
\text { area }\end{array}$ & no & no & no & yes \\
\hline Storage area & yes & yes & yes & yes \\
\hline Toilets area & yes & yes & yes & yes \\
\hline $\begin{array}{c}\text { Change } \\
\text { rooms area }\end{array}$ & yes & no & yes & yes \\
\hline $\begin{array}{c}\text { Supermarket } \\
\text { area }\end{array}$ & yes & no & no & no \\
\hline
\end{tabular}

The building was simulated during the winter/summer periods using a typical Bucharest weather file which contains hourly values for dry bulb temperature, wet bulb temperature, diffuse solar radiation, direct solar radiation, wind speed and wind direction. The simulation results file includes internal air temperatures, air flows rates between zones and outside, heating and cooling loads for each building zone.

According to the new construction building project, as described in the chapter 1 of the paper, we obtained the building energy performances for the executed building. In Table 3, Table 4 and Figure 1 there are obtained for winter time $7,830,000.00 \mathrm{kWh}$ total building heating consumption per thermal zone type and level during a year. The figure 1 shows the building heating per level and its distribution for tenants and for the building considering having no shops (all spaces not meant for the tenants' areas.)

In the Table 5, Table 6 and Figure 2 there are obtained for summer time $902,400.00 \mathrm{kWh}$ total building cooling consumption per thermal zone type and per level. Equivalent specific annual emission indicator for the designed building is $21.58 \mathrm{kgCO}_{2} / \mathrm{m}^{2} *$ year [3].

Table 3. Building heating consumption per thermal zone type

\begin{tabular}{|c|c|}
\hline Thermal zone type & $\begin{array}{c}\text { Total Building heating } \\
\text { per thermal zone type } \\
\text { (\%) }\end{array}$ \\
\hline technical & 0.17 \\
\hline shops $>1000 \mathrm{~m}^{2}$ & 42.68 \\
\hline shops $<1000 \mathrm{~m}^{2}$ & 34.90 \\
\hline toilets & 0.30 \\
\hline storages & 0.63 \\
\hline gastro & 0.01 \\
\hline fitness area & 0.03 \\
\hline restaurants & 0.12 \\
\hline conference rooms & 0.08 \\
\hline
\end{tabular}

\begin{tabular}{|c|c|}
\hline $\begin{array}{c}\text { building public areas } \\
\text { (corridors/ } \\
\text { lobbies) }\end{array}$ & 15.55 \\
\hline offices & 0.34 \\
\hline change areas & 0.19 \\
\hline $\begin{array}{c}\text { Super- } \\
\text { market }\end{array}$ & 5.01 \\
\hline Total building heating (\%) & 100.00 \\
\hline
\end{tabular}

Building heating per level

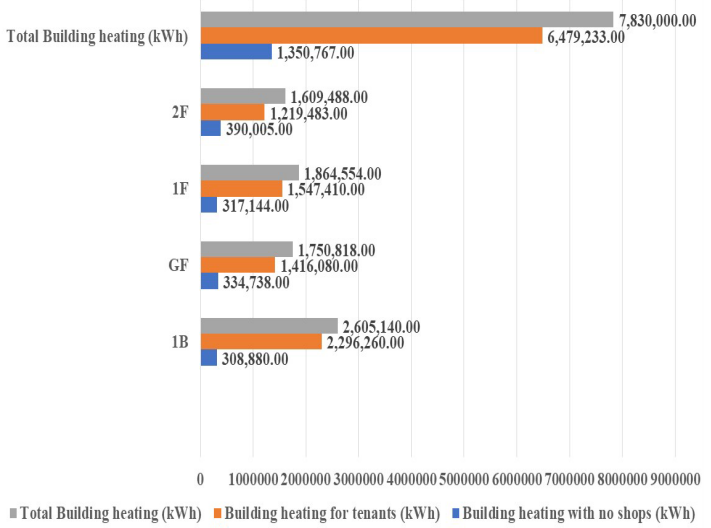

Fig. 1. Building heating per each level

The figure 1 shows the building heating per level and its distribution for tenants and for the building considering having no shops (all spaces not meant for the tenants' areas) with a total of $7,830,000.00 \mathrm{kWh}$ for the entire building from which $1,6479,233.00 \mathrm{kWh}$ is for the tenants, meaning a percentage of $82.75 \%$.

Table 4. Building heating consumption per level and year $(\%)$

\begin{tabular}{|c|c|c|c|}
\hline $\begin{array}{c}\text { Building } \\
\text { heating } \\
\text { per level } \\
\text { (\%) }\end{array}$ & $\begin{array}{c}\text { Building } \\
\text { heating with } \\
\text { no shops } \\
\text { (\%) }\end{array}$ & $\begin{array}{c}\text { Building } \\
\text { heating for } \\
\text { tenants (\%) }\end{array}$ & $\begin{array}{c}\text { Total } \\
\text { Building } \\
\text { heating (\%) }\end{array}$ \\
\hline 1B & $22.87 \%$ & $35.44 \%$ & $33.27 \%$ \\
\hline GF & $24.78 \%$ & $21.86 \%$ & $22.36 \%$ \\
\hline 1F & $23.48 \%$ & $23.88 \%$ & $23.81 \%$ \\
\hline $2 \mathrm{~F}$ & $28.87 \%$ & $18.82 \%$ & $20.56 \%$ \\
\hline $\begin{array}{c}\text { Total } \\
\text { Building } \\
\text { heating } \\
\text { (\%) }\end{array}$ & $17.25 \%$ & $82.75 \%$ & $100 \%$ \\
\hline
\end{tabular}

The figure 2 shows the building cooling per level and its distribution for tenants and for the building considering having no shops (all spaces not meant for the tenants' areas) with a total of $902,400.00 \mathrm{kWh}$ for the entire building from which $626,444.00 \mathrm{kWh}$ is for the tenants, meaning a percentage of $69.42 \%$. 


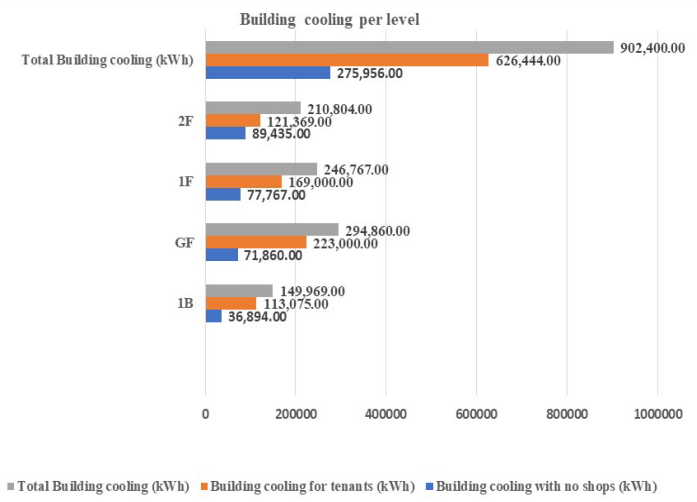

Fig. 2. Building cooling per each level

Table 5. Building cooling consumption per thermal zone type

\begin{tabular}{|c|c|}
\hline Thermal zone type & $\begin{array}{c}\text { Total Building cooling per } \\
\text { thermal zone type (\%) }\end{array}$ \\
\hline technical & 0.00 \\
\hline shops $>1000 \mathrm{~m}^{2}$ & 17.23 \\
\hline shops $<1000 \mathrm{~m}^{2}$ & 49.12 \\
\hline toilets & 0 \\
\hline storages & 0 \\
\hline gastro & 0.44 \\
\hline fitness area & 0.10 \\
\hline restaurants & 0.64 \\
\hline conference rooms & 0.15 \\
\hline $\begin{array}{c}\text { building public areas } \\
\text { corridors/lobbies) }\end{array}$ & 29.09 \\
\hline offices & 1.08 \\
\hline change areas & 0.26 \\
\hline Supermarket & 1.89 \\
\hline Total building cooling (\%) & 100.00 \\
\hline
\end{tabular}

Table 6. Building cooling consumption per level and year $(\%)$

\begin{tabular}{|c|c|c|c|}
\hline $\begin{array}{c}\text { Building } \\
\text { cooling } \\
\text { per level } \\
(\%)\end{array}$ & $\begin{array}{c}\text { Building } \\
\text { cooling with } \\
\text { no shops } \\
\text { (\%) }\end{array}$ & $\begin{array}{c}\text { Building } \\
\text { cooling for } \\
\text { tenants } \\
(\%)\end{array}$ & $\begin{array}{c}\text { Total } \\
\text { Building } \\
\text { cooling } \\
\text { (\%) }\end{array}$ \\
\hline 1B & $13.37 \%$ & $18.05 \%$ & $16.62 \%$ \\
\hline GF & $26.04 \%$ & $35.60 \%$ & $32.68 \%$ \\
\hline 1F & $28.18 \%$ & $26.98 \%$ & $27.35 \%$ \\
\hline $2 \mathrm{~F}$ & $32.41 \%$ & $19.37 \%$ & $23.36 \%$ \\
\hline $\begin{array}{c}\text { Total } \\
\text { Building } \\
\text { cooling } \\
\text { (\%) }\end{array}$ & $30.58 \%$ & $69.42 \%$ & $100 \%$ \\
\hline
\end{tabular}

For the winter time it was considered the period between the $1^{\text {st }}$ of January and $15^{\text {th }}$ of May and $16^{\text {th }}$ of September and $31^{\text {st }}$ of December resulting in a percentage of $83 \%$ for tenants' heating space from the total building heating space. For the designed building, the building heating load considered was $3924 \mathrm{~kW}$ from which, by zone we have established, as follows: $1110 \mathrm{~kW}$ for $1 \mathrm{~B}, 860 \mathrm{~kW}$ for $\mathrm{GF}, 933 \mathrm{~kW}$ for $1 \mathrm{~F}$ and $1021 \mathrm{~kW}$ for $2 \mathrm{~F}$ having considered the design temperature of $-15^{\circ} \mathrm{C} /$ winter and $+35^{\circ} \mathrm{C} /$ winter and an internal heat gain of $15 \mathrm{~W} / \mathrm{m}^{2}$. The heating maximum demand was obtained around 5 a.m. with no internal heat gains when the building started the heat before the official opening hour of the major shops' activities. The choice of the boilers was correctly sized.

For the summer time it was considered the period between the $16^{\text {th }}$ of May and $15^{\text {th }}$ of October resulting in a percentage of $80 \%$ for tenants' cooling space from the total building heating space. For the designed building, the building cooling load considered was $1836 \mathrm{~kW}$ from which, by zone we have established, as follows: $422 \mathrm{~kW}$ for $1 \mathrm{~B}, 465 \mathrm{~kW}$ for $\mathrm{GF}, 476 \mathrm{~kW}$ for $1 \mathrm{~F}$ and $473 \mathrm{~kW}$ for $2 \mathrm{~F}$ having considered the design temperature of $-15^{\circ} \mathrm{C} /$ winter and $+35^{\circ} \mathrm{C} /$ winter and an internal heat gain of $15 \mathrm{~W} / \mathrm{m}^{2}$. The cooling maximum demand was obtained at $1841 \mathrm{~kW}$ at $4 \mathrm{p} . \mathrm{m}$. for an internal heat gain as of $15 \mathrm{~W} / \mathrm{m}^{2}$. The estimated demand is higher and it is meant to cover the worstcase scenario of internal heat gains.

Because the building is a commercial building and has specific tenants' requests, during the period between the $16^{\text {th }}$ of September and $15^{\text {th }}$ of October, it was considered for the summer time both types of cooling and heating space situations due to the exterior temperatures' conditions.

\section{Conclusions}

The building design is very well made and covers very well the worse case scenario for heating and cooling periods as it was very well shown within the building thermal modelling. From the total heating space energy, the tenants are consuming around $83 \%$ and the rest is used for the building needs. In the case of the building cooling, the tenants are consuming around $70 \%$ and the rest is for the building requirements. In order to obtain a better energy efficient building and to lower the energy consumptions, it is important to request to the tenants and to check right from the beginning of their design and execution works to implement projects designs for execution with construction elements which are fulfilling all building design and building thermal modelling. Also, the preventive maintenance and technical revisions of all installations and equipment of the tenants and building must follow up the maintenance operational plan of the building imposed by the landlord. 
By introducing energy efficient technical measures, the building energy performances will be improved. Such measures previewed are [3]: to maximize the U values of non-transparent construction elements; to use transparent construction elements with a better $U$ value and ensuring the thermal comfort and preventing the lower condensation risk; to maximize the free night cooling in all zones by mechanical ventilation and to have natural free night cooling in the public building areas, food through the roof openings; to use the heat recovery for all shops and building areas; to decrease the air set point temperature for the winter time by $2^{0} \mathrm{C}$ from $24^{0} \mathrm{C}$ to $22^{\circ} \mathrm{C}$ and to reduce the heating consumption; to decrease the air set point temperature for the summer period by $2{ }^{\circ} \mathrm{C}$ from $26^{\circ} \mathrm{C}$ to $24^{\circ} \mathrm{C}$ and to reduce the cooling consumption value.

Acknowledgements are addressed to the landlord and to the facility management teams for providing us with the access to the installations and for their kind support during our work on the building modelling and on the building services systems monitoring.

\section{References}

1. E. C. Tamaș, D. Hera., Dynamic thermal simulations for the internal heat gains and opening hours in a commercial building-mall, Sustainable Solutions for Energy and Environment EENVIRO Proceedings Conference, EENVIRO Bucharest (2013)

2. E. C. Tamaş, G. M. Țârlea, D. Hera., G. Flamaropol, Energy consumption and data for the internal heat gains and opening hours at a commercial building, 17th International Multidisciplinary Scientific Geo Conference, Green Buildings Technologies and Materials, SGEM Vienna (2017)

3. E. C. Tamaș (Papuc), Energy consumption monitoring and building performances in a commercial building - Case study, 10th International Conference on Improving Energy Efficiency in Commercial Buildings and Smart Communities, IEECB\&SC18 Frankfurt (2018) (to be published)

4. https://www.codesys.com/products/codesysservices.html

5. https://www.progea.com/en/movicon-11/ 